\title{
KEPATUHAN IBU HAMIL DALAM MELAKUKAN \\ PEMERIKSAAN KEHAMILAN DI DESA SIDOREJO, KECAMATAN PULOKULON, KABUPATEN GROBOGAN
}

\author{
Dary $^{1^{*}}$, Arwyn W. Nusawakan ${ }^{2}$, Fitria Setyaningrum ${ }^{3}$ \\ ${ }^{\star 1,2,3}$ Program Studi IImu Keperawatan, Fakultas Kedokteran dan IImu Kesehatan, Universitas Kristen Satya \\ Wacana Jln. Kartini No.11 A, email: dary@staff.uksw.edu
}

\begin{abstract}
Background: Maternal health has become one barometer of achievement of a country, especially developing countries like Indonesia. AKI Indonesia is 359 per 100,000 live births, not in accordance with MDGs target in 2015 that is 102 deaths per 100,000 live births. One of the causes of high AKI is because mothers do not utilize Antenatal Care (ANC) visit. Antenatal Care (ANC) is a professional health service (doctors specialist, general practitioner, midwife, and nurse) for the mother during her pregnancy in accordance with antenatal care standards.

Objective: The purpose of this research is to know factors related to maternity compliance in performing pregnancy examination and to correlate each factor with the compliance.

Methods: Sample of this quantitative study was mother who experienced pregnancy and has child younger than 3 year old living in Sidorejo village. 30 samples were recruited and then asked to fill in questionnaire. The data were analysed by using Correlation Spearman.

Results: Very weak relationship between 7 maternal attributes with their obedience regarding examination of pregnancy found in this study namely age 0.030 , employment 0.067 , health insurance ownership 0.089 , parity 0.017 , history of pregnancy examination 0.019 , Family support 0.083 , and culture -0.098 , while incomes 0.247 and knowledge 0.222 attributes indicate weak relationship level.

Conclusion:There are relationships weak and very weak between the ages of, work, income, ownership health insurance, of parity, the acts of examination pregnancy, knowledge , family encouragement, culture and compliance mother in melakkan anc
\end{abstract}

Keywords: Antenatal care, adherence

\section{PENDAHULUAN}

Angka Kematian lbu (AKI) adalah jumlah kematian ibu selama kehamilan, persalinan dan nifas atau pengelolaannya tetapi bukan karena sebab-sebab lain seperti kecelakaan, terjatuh, di setiap 100.000 kelahiran hidup. Kesehatan maternal menjadi salah satu barometer ketercapaian suatu negara, khususnya negara berkembang seperti Indonesia. Berdasarkan Profil Kesehatan Kabupaten Grobogan tahun 2014, AKI di Kabupaten Grobogan per 100.000 kelahiran hidup sebanyak 189 dengan 43 kasus (10 kasus kematian masa hamil dan 33 kasus kematian pada masa nifas). ${ }^{12}$
Tingginya AKI disebabkan oleh beberapa faktor, diantaranya yaitu latar belakang pendidikan, sosial ekonomi, lingkungan masyarakat, pandangan bahwa kehamilan adalah peristiwa alamiah dan yang tidak kalah pentingnya adalah faktor pengawasan selama kehamilan yaitu ante natal care (ANC). Akibat dari ketidak patuhan dalam memanfaatkan ANC membuat ibu berisiko dapat mengalami masalah kesehatan.

Tujuan dilakukannya ANC adalah untuk mempromosikan dan menjaga kesehatan fisik, mental ibu dan bayi, serta mendeteksi dan menatalaksanakan 
komplikasi medis, bedah, maupun obstetric, mengembangkan persiapan persalinan, membantu menyiapkan ibu untuk menyusui, merawat anak secara fisik, psikologi dan sosial. $^{3}$

Manfaat melakukan ANC yaitu memfasilitasi hasil yang sehat dan positif bagi ibu hamil maupun bayinya dengan alasan menegakkan hubungan kepecayaan ibu, mendeteksi komplikasi yang yang dapat mengancam jiwa, mempersiapkan kelahiran dan memberikan pendidikan kesehatn. ${ }^{4}$

Tujuan dilakukannya penelitian ini adalah untuk mengetahui faktor-faktor yang berhubungan dengan kepatuhan ibu hamil dalam melakukan pemeriksaan kehamilan (ANC) dan hubungan setap faktor (atribute) dengan kepatuhan ibu melakukan ANC.

\section{BAHAN DAN CARA PENELITIAN}

Penelitian ini merupakan penelitian kuantitatif yang dilakukan di Desa Sidorejo, Kecamatan Pulokulon, kabupaten Grobogan, pada bulan April 2017. Total responden 30 orang yaitu ibu yang pernah hamil dengan usia anak $\leq 3$ tahun yang dipilih secara purposive sampling. Pengumpulan data menggunakan angket yang dibuat oleh peneliti dan didukung dengan informasi dari catatan buku KIA ibu. Alat ukur yang digunakan adalah aplikasi SPSS versi 16 dengan menggunakan analisa data Correlation Spearman.

\section{HASIL DAN PEMBAHASAN}

Tabel hasil penelitian dibawah ini menjelaskan mengenai distribusi responden berdasarkan profil demografi dan hubungan antara faktor-faktor dalam profil demografi (usia, pekerjaan, penghasilan, kepemilikan asuransi kesehatan, riwayat hamil, riwayat pemeriksaan kehamilan, pengetahuan minimal kunjungan ANC, dukungan keluarga, budaya) dengan kepatuhan ibu hamil dalam melakukan kunjungan

ANC.

Tabel 1. Distribusi demografi responden

\begin{tabular}{llrr}
\hline & Karakteristik & f & $\%$ \\
\hline Usia & $<20$ tahun & 13 & 43 \\
& $20-35$ tahun & 17 & 57 \\
Pekerjaan & $>35$ tahun & 0 & 0 \\
& Bekerja & 22 & 73 \\
Penghasilan & Tidak bekerja & 8 & 27 \\
& $<1.000 .000$ & 7 & 23 \\
& $1.000 .000-3.000 .000$ & 23 & 77 \\
Kepemilikan Asuransi Kesehatan & $3.000 .000-5.000 .000$ & 0 & 0 \\
Riwayat hamil & $>5.000 .000$ & 0 & 0 \\
& Iya & 15 & 50 \\
Jumlah kunjungan ANC & Tidak & 15 & 50 \\
& $\leq 2$ kali & 25 & 83 \\
& $>2$ kali & 5 & 17 \\
& Sesuai K1 & 29 & 97 \\
\hline
\end{tabular}




\begin{tabular}{llrr}
\hline & Karakteristik & f & \% \\
\hline & Sesuai K2 & 30 & 100 \\
Pemberi Layanan ANC & Sesuai K3-K4 & 29 & 97 \\
& Bidan & 30 & 100 \\
Alasan periksa ANC & Dukun & 0 & 0 \\
& Menjaga KIA & 29 & 97 \\
Pengetahuan standar minimal & Ada keluhan & 1 & 3 \\
kunjungan ANC & 4 & 24 & 80 \\
& 3 & 4 & 13 \\
Dukungan keluarga & 2 & 2 & 7 \\
& 1 & 0 & 0 \\
Aksesibilitas (jarak) & lya & 29 & 97 \\
Kondisi jalan & Tidak & 1 & 3 \\
& $\leq 2$ km & 30 & 100 \\
Jumlah dukun & $>2$ km & 0 & 0 \\
& Baik & 0 & 0 \\
Budaya & Sedang & 5 & 17 \\
Total & Buruk & 25 & 83 \\
& $\leq 2$ & 22 & 73 \\
& $>2$ & 8 & 27 \\
& Datang ke dukun & 22 & 73 \\
& Tidak datang ke dukun & 8 & 27 \\
& & 30 & 100 \\
\hline
\end{tabular}

Dari hasil uji statistik menggunakan Spearman, diperoleh nilai Correlation Coefficient $=0,030$ artinya terdapat hubungan antara usia responden dengan kepatuhan ibu hamil dalam melakukan ANC. Correlation Coefficient $=0,030$ tergolong sangat lemah (0,00-0,199). Diperkirakan artinya adalah semakin dewasa usia responden semakin patuh dalam melakukan pemeriksaan kehamilan. $^{5}$

Pada penelitian ini, mayoritas responden memiliki usia 20-35 tahun (57\%), pada usia tersebut dapat dikatakan bahwa seorang wanita memiliki kematangan reproduksi, emosional maupun aspek sosial. Hasil penelitian ini sejalan dengan pendapat Marmi yang menyatakan bahwa kehamilan paling ideal bagi seorang wanita adalah saat usianya berada pada rentang 20-35 tahun.
Usia dibawah 20 tahun dikhawatirkan memiliki resiko komplikasi yang erat kaitannya dengan kesehatan reproduksi wanita, dan usia diatas 35 tahun memiliki resiko tinggi karena adanya kemunduran fungsi alat reproduksi. ${ }^{6}$

Pada umumnya, masyarakat yang lebih dewasa usianya akan lebih dipercaya daripada orang yang belum cukup tinggi tingkat kedewasaannya. Semakin dewasa seseorang, maka cara berfikir semakin matang dan teratur melakukan ANC. ${ }^{7,8}$ Dari hasil penelitian, terdapat responden yang berusia <20 tahun yaitu sebanyak 13 responden (43\%), usia tersebut termasuk usia dibawah ideal untuk seseorang hamil, namun ternyata responden tersebut patuh dalam melakukan ANC. Hal ini yang menjadi penyebab nilai korelasi antara usia 
responden dengan kepatuhan memiliki nilai korelasi sangat lemah. Ternyata, berapapun usia mereka, responden beranggapan bahwa pemeriksaan kehamilan merupakan hal penting yang harus dilakukan guna menjaga kesehatan ibu dan janin.

Hasil uji Sperman menunjukan nilai Correlation Coefficient $=0,067$ artinya terdapat korelasi antara pekerjaan dengan kepatuhan ibu hamil dalam melakukan ANC. Dapat diketahui bahwa ibu yang bekerja akan lebih patuh dalam melakukan ANC dibandingkan dengan ibu yang tidak bekerja. Nilai Correlation Coefficient $=0,067$ tergolong sangat lemah $(0,00-0,199){ }^{5}$

Dalam hasil penelitian ini, responden memiliki pekerjaan sebagai guru sebanyak 3 orang $(10 \%)$, sebagai pedagang 2 orang (7\%) dan sisanya sebagai petani sebanyak 17 orang (56\%). Biasanya, keluarga dengan ekonomi (pekerjaan) yang cukup baik dapat memeriksakan kehamilannya secara rutin dan melakukan persiapan lainnya dengan baik. ${ }^{9}$

Sebanyak 22 responden menyatakan bekerja $(73 \%)$ dan mereka patuh terhadap kunjungan ANC. Begitu pula dengan 8 orang yang tidak bekerja (27\%) juga patuh terhadap pemeriksaan kehamilan. Responden yang bekerja tetap menyempatkan waktu untuk melakukan pemeriksaan kehamilan di selasela kesibukannya. Begitu pula dengan responden yang tidak bekerja melakukan pemeriksaan kehamilan dengan informasi dan pengalaman yang dimilikinya.
Responden yang bekerja dan responden yang tidak bekerja menganggap bahwa melakukan pemeriksaan kehamilan adalah kewajiban yang harus dilakukan tanpa didasari apa pekerjaan mereka.

Hasil uji Sperman menunjukan nilai Correlation Coefficient $=0,247$ artinya terdapat korelasi antara penghasilan dengan kepatuhan ibu hamil dalam melakukan ANC. Artinya semakin tinggi penghasilan semakin patuh dalam melakukan ANC. Nilai Correlation Coefficient $=0,247$ tergolong lemah $(0,20-0,399) .^{5}$

Mayoritas responden (23 responden atau $77 \%$ ) memiliki penghasilan kisaran 1.000.000-3.000.000 (cukup), sebanyak 7 keluarga (23\%) memiliki penghasilan < 1.000 .000 (kurang). Menurut Purwoastuti (2015) status ekonomi adalah kedudukan seseorang atau keluarga di masyarakat berdasarkan pendapatan perbulan. Keluarga dengan ekonomi yang cukup dapat memeriksakan kehamilan secara rutin dan melakukan persiapan lainnya dengan baik. Keadaan ekonomi sangat mempengaruhi kehamilan ibu, karena berhubungan dengan pemenuhan kebutuhan-kebutuhan ibu selama kehamilan. ${ }^{9} 1011$

Pada hasil penelitian ini menunjukan bahwa responden yang memiliki penghasilan cukup, mereka patuh terhadap pemeriksaan kehamilan. Begitu pula dengan responden yang berpenghasilan kurang, ternyata mereka juga patuh terhadap ANC. Hasil penelitian ini menunjukan bahwa berapapun 
penghasilan keluarga perbulan, hal tersebut hanya berpengaruh lemah terhadap kepatuhan dalam memeriksakan kehamilan. Responden patuh terhadap pemeriksaan kehamilan, karena mereka beranggapan bahwa pemeriksaan kehamilan merupakan hal yang harus dilakukan guna menjaga kesehatan ibu dan janin. Penghasilan keluarga tidak menjadi tolak ukur untuk kepatuhan dalam memeriksakan kehamilan.

Dari hasil uji Spearman, diperoleh nilai Correlation Coefficient $=0,089$ artinya terdapat korelasi antara kepemilikan asuransi kesehatan dengan kepatuhan ibu dalam melakukan ANC. Artinya responden yang memiliki asuransi kesehatan akan lebih patuh terhadap pemeriksaan ANC dibandingkan responden yang tidak memiliki asuransi kesehatan. Nilai 0,089 tergolong sangat lemah $(0,00-0,199) .^{5}$

Sebanyak 15 keluarga (50\%) memiliki asuransi kesehatan dan sisanya tidak memiliki. Kepemilikan Askes dapat meningkatkan kepatuhan seseorang dalam menjaga kesehatannya. Seperti hasil penelitian dari lgna (2016) yang menyatakan bahwa kepemilikan asuransi kesehatan di Ghana dapat meningkat secara pesat pada kesehatan maternal. ${ }^{12}$

Responden yang memiliki asuransi kesehatan cenderung patuh dalam melaksanakan ANC. Namun tidak berarti responden yang tidak memiliki asuransi kesehatan tidak patuh dalam melaksanakan ANC. Hal ini yang menyebabkan lemahnya tingkat korelasi antara kepemilikan asuransi kesehatan dengan kepatuhan.

Hasil penelitian ini sejalan dengan penelitian yang dilakukan oleh Edson (2015) yang menyatakan bahwa tidak ada perbedaan yang signifikan antara pengguna asuransi dengan yang tidak menggunakan asuransi dalam kepatuhan melakukan ANC. Semua responden baik yang memiliki asuransi maupun tidak, menganggap bahwa melakukan ANC adalah suatu hal yang harus dilakukan guna menjaga kesehatan.

Hasil uji Spearman menunjukan nilai Correlation Coefficient $=0,017$ artinya terdapat korelasi antara riwayat hamil responden dengan kepatuhan ibu dalam melakukan ANC. Dapat diartikan bahwa ibu yang pernah hamil $\leq 2$ kali akan lebih patuh melakukan ANC dibandingkan dengan ibu yang pernah hamil $>2$ kali. Nilai 0,017 tergolong sangat lemah $(0,00-0,199) .^{12}$

Dari hasil penelitian ini, mayoritas responden (25 orang atau $83 \%$ ) pernah hamil kurang dari atau dua kali dan sisanya (5 orang atau 17\%) pernah hamil $>2$ kali. Paritas adalah faktor utama yang memengaruhi wanita menerima kurang dari empat kali kunjungan ANC selama kehamilan. Hal ini sesuai dengan hasil penelitian dari Gita (2015) yang menyatakan bahwa ada hubungan antara paritas dengan pemanfaatan pelayanan ANC. ${ }^{13,14}$

Pada umumnya, ibu primigravida merasa lebih khawatir dengan kehamilannya, karena belum memiliki pengalaman hamil 
dan informasi lain tentang kehamilan. Berbeda dengan ibu multigravida yang sudah berpengalaman lebih dulu dan memiliki informasi dari kehamilan sebelumnya. Seberapa banyak responden pernah hamil, ternyata hanya berpengaruh sangat lemah terhadap kepatuhan melakukan ANC. Hal ini dikarenakan ibu dengan primigravida dan multigravida sama-sama merasa membutuhkan informasi mengenai kesehatan ibu dan janin.

Hasil uji Spearman menunjukan nilai Correlation Coefficient $=0,019$ artinya terdapat korelasi antara riwayat pemeriksaan kehamilan responden dengan kepatuhan ibu hamil dalam melakukan ANC. Dapat diartikan jika responden yang memenuhi standart minimal kunjungan ANC dengan pola 1-1-2 (1 kali pada trimester 1, 1 kali pada trimester 2 dan 2 kali pada trimester 3) akan dinilai lebih patuh dalam melakukan ANC dibandingkan dengan responden yang tidak memenuhi standart ANC. Nilai 0,019 tergolong sangat rendah $(0,00-0,199) .5,15$

Mayoritas responden (29 atau 97\%) dinilai patuh terhadap kunjungan $\mathrm{K} 1$ yaitu minimal 1 kali kunjungan pada trimester pertama, 1 responden (3\%) tidak patuh karena pada trimester 1 kehamilan responden tersebut tidak memeriksakan kehamilan dikarenakan tidak mengetahui keadaannya yang sedang hamil, maka responden tersebut baru memeriksakan kehamilannya pada awal trimester kedua.
Semua responden (30 atau 100\%) patuh terhadap K2. Sebanyak 29 responden (97\%) patuh terhadap K3 dan K4. Satu responden $(3 \%)$ tidak patuh terhadap $\mathrm{K} 4$ karena hanya melakukan ANC sebanyak 1 kali pada kehamilan trimester 3 . Hal tersebut dikarenakan responden melahirkan pada usia kehamilan 7 bulan. Jadi, responden hanya melakukan pemeriksaan sebanyak 1 kali di awal trimester ke 3. Hasil uji Spearman menunjukan nilai Correlation Coefficient $=$ 0,222 artinya terdapat korelasi antara pengetahuan dengan kepatuhan ibu hamil dalam melakukan ANC. Nilai 0,222 tergolong rendah (0,20-0,399). Dapat diartikan jika semakin baik pengetahuan, maka responden akan semakin patuh terhadap kunjungan ANC. ${ }^{5}$

Dari hasil penelitian, diperoleh hasil adanya hubungan yang sangat lemah antara pengetahuan ibu mengenai standar kunjungan ANC dengan kepatuhan dalam melakukan kunjungan ANC. Hal ini didukung oleh hasil penelitian Rahma (2013) yang menjelaskan bahwa tidak terdapat hubungan yang bermakna antara pengetahuan terhadap kunjungan pemeriksaan kehamilan (ANC). Hasil penelitian ini sejalan juga dengan penelitian dari Haerani (2009) yang menunjukkan tidak adanya hubungan yang bermakna antara tingkat pengetahuan ibu hamil dengan kepatuhan dalam melakukan ANC. ${ }^{16,17}$

Hasil uji Sperman menunjukan nilai Correlation Coefficient $=0,083$ artinya 
terdapat hubungan antara dukungan keluarga dengan kepatuhan ibu hamil dalam melakukan ANC. Dapat diartikan bahwa responden yang memiliki dukungan keluarga akan lebih patuh dibandingkan dengan responden yang tidak memiliki dukungan keluarga.Nilai 0,083 tergolong sangat rendah $(0,00-0,199) .^{5}$

Dari hasil penelitian, ditemukan mayoritas responden (29 atau 97\%) dengan dukungan keluarga dan sisanya (1 atau $3 \%$ ) tanpa dukungan keluarga. Dukungan suami atau keluarga merupakan dorongan, motivasi terhadap istri, baik secara moral maupun material. ${ }^{18}$ Hasil penelitian dari Gita (2015) ditemukan responden tanpa dukungan suami tidak teratur dalam pemanfaatan pelayanan ANC. Hal ini sejalan dengan penelitian Faijah (2012) yang menemukan sebanyak $68,47 \%$ dukungan suami yang kurang pada istrinya berpengaruh terhadap keinginan istri untuk melakukan ANC. Hasil penelitian lain yang mendukung penelitian ini adalah penelitian yang dilakukan oleh Halim (2010) tentang pelayanan ANC untuk kesehatan di Nepal menunjukan bahwa dukungan keluarga merupakan faktor yang mempengaruhi ibu hamil untuk memanfaatkan pelayanan ANC. ${ }^{14,19,20}$ Dukungan keluarga memiliki hubungan yang sangat lemah dengan kepatuhan dalam melakukan ANC. Dengan atau tanpa dukungan suami, ternyata responden tetap melakukan pemeriksaan kehamilan. Hasil uji Sperman menunjukan nilai Correlation Coefficient $=-0,098$ artinya terdapat korelasi berlawanan antara kepatuhan ibu hamil dalam melakukan ANC dengan budaya. Pada umumnya, jika responden patuh terhadap pemeriksaan ke tenaga kesehatan, maka responden tersebut tidak datang ke dukun. Pada hasil penelitian menunjukan nilai negatif, berarti dapat diartikan responden patuh melakukan ANC kepada tenaga kesehatan, namun masih tetap datang ke dukun.

Berdasarkan hasil penelitian, mayoritas responden (22 atau 73\%) mengikuti budaya tradisional yang masih melakukan pemeriksaan kehamilan di dukun dan sisanya hanya melakukan pemeriksaan di tenaga kesehatan. Ada 22 responden yang selain melakukan ANC di tenaga kesehatan, mereka juga periksa ke dukun. Alasan mereka datang ke dukun adalah mengikuti tradisi keluarga yang setiap kali hamil harus diperiksakan juga ke dukun pijat atau beranak. Hal tersebut dilakukan guna menjaga keutuhan dan kelestarian tradisi yang sudah turun temurun dilakukan. Hal diatas sependapat dengan Kathleen (2015) yang menyatakan bahwa beberapa keluarga pedesaan di Thailand memilih melakukan perawatan kehamilan pada rumah tradisional yang menggunakan budaya praktik kehamilan yang sudah turun temurun dilakukan. Penelitian lain yang mendukung adalah penelitian dari Khatia (2016) yang menyatakan bahwa beberapa masyarakat masih menggunakan tua-tua adat sebegai pemberi layanan ANC dan persalinan. Tua- 
tua adat dipercaya sebagai pemberi jasa yang baik karena sudah digunakan secara turun temurun oleh keluarga terdahulu. Jasa dukun beranak untuk antenatal, persalinan, dan nifas secara luas digunakan dan peran mereka dalam perawatan ibu dan anak dianggap penting oleh beberapa anggota masyarakat. ${ }^{4,21}$

Beberapa faktor yang telah diteliti tersebut menunjukan hubungan yang lemah dan sangat lemah dengan tingkat kepatuhan anc sehingga menurut analisis peneliti terdapat faktor lain yang memungkinkan masyarkat dalam konteks penelitian ini menjadi patuh untuk memeriksakan kehamilan mereka. Faktor tersebut seperti kesadaran yang dimiliki masyarakat setempat dan juga sikap tenaga kesehatan yang membuat ibu hamil patuh untuk melaksanakan ANC di layanan kesehatan.

\section{KEPUSTAKAAN}

1. Profil Kesehatan Indonesia 2015

2. Profil Kesehatan Kabupaten Grobogan 2014

3. Kusmiati, dkk. 2008. Panduan Lengkap Perawatan Kehamilan. Yogyakarta:Fitramaya

4. Mufdlilah. 2009. Antenatal Care Focus. Yogyakarta: Nuha Medika

5. Sugiyono. 2008. Metode Penelitian Kualitatif, Kuantitatif dan R\&D cetakan ke 19. Bandung: Alfabeta

6. Marmi. 2011. Ashan Kebidanan Pada Ibu Hamil. Yogyakarta: Penerbit Pelajar

7. Christiani Ninik, dkk. 2014

8. Putri K.D. Shinta, dkk. 2014

9. Indriyani. 2013. Aplikasi Konsep Dan Teori Keperawatan Maternitas postpartum Dengan Kematian Janin. Yogyakarta: Ar-Ruzz Media
Hal ini senada dengan beberapa hasil studi yang menyebutkan bahwa terdapat hubungan yang kuat antara sikap petugas kesehatan dan kesadaran ibu hamil tentang pentingnya melakukan anc dengan tingkat kepatuhan pemeriksaan anc. ${ }^{22} 23$

\section{KESIMPULAN}

Hasil penelitia ini menyimpullkan bahwa terdapat hubungan yang lemah dan sangat lemah antara usia, pekerjaan, penghasilan, kepemilikan asuransi kesehatan, paritas, riwayat pemeriksaan kehamilan, pengetahuan, dukungan keluarga, budaya dan kepatuhan ibu dalam melakkan ANC. Faktor lain yang bisa berhubungan kuat dan dibutuhkan penelitian lebih lanjut dalam konteks penelitian ini adalah terkait faktor kesadaran ibu dan sikap petugas kesehatan.

10. Purwoastuti, dkk. 2015. Panduan Materi Kesehatan Reproduksi dan Keluarga Berencana. Yogyakarta: Pustaka Baru

11. Rukiyah. 2009. Asuhan Kebidanan 1. Jakarta: Transinfo Medika

12. Bonfrer Igna, dkk. 2016. The Effects of Ghana's National Health Insurance Scheme on Maternal and Infant Health Care Utilization.

13. Yenita Agus, Horiuchi Shigeko. 2012. Factors influencing the use of antenatal care in rural West Sumatra, Indonesia

14. Sari Gita Nirmala,dkk. 2015.Jurnal IImu dan Teknologi Kesehatan, Vol. 2, Nomor 2, Maret 2015, hlm : $77-82$

15. Sulistyawati, Ari. 2009. Buku Ajar Asuhan Kebidanan pada lbu Nifas. Yogyakarta: salemba Medika

16. Erlina Rahma. 2013. Faktor-faktor yang Pempengaruhi Ibu Hamil Terhadap Pemeriksaan Kehamilan di 
Puskesmas Rawat Inap Panjang Bandar Lampung: Medical Jurnal of Lampung University. Volume 2 No. 4 Februari 2013

17. Haerani, S. 2009. Dalam skripsi Linda Wattimena dengan judul Hubungan Tingkat Pengetahuan dan Sikap lbu Hamil tentang Pertumbuhan Janin dengan Kepatuhan lbu Hamil dalam Melakukan ANC pada Tahun 2011

18. Bobak. 2005. Keperawatan Keluarga. Jakarta: EGC
19. Sihombing Faijah. 2012. Hubungan dukungan suami terhadap kunjungan ANC

20. Halim. Standar Pelayanan ANC. 2010

21. Putri K.D. Shinta, dkk. 2014

22. Hasana Uswatul. 2014. Faktor Yang Berhubungan Dengan Pemanfaatan Antenatal Care Di Puskesmas Antara Kota Makassar

23. Erlina Rahma. 2012. Faktor-Faktor Yang Mempengaruhi lbu Hamil Terhadap Kunjungan Pemeriksaan Kehamilan Di Puskesmas Rawat Inap Panjang Bandar Lampung 